\title{
SELECTION OF THE INSULATION MATERIALS FOR REFURBISHMENT PURPOSES
}

\author{
Irene LILL ${ }^{\mathrm{a}}$, Loreta KANAPECKIENE ${ }^{\mathrm{b}}$, Laura TUPENAITE ${ }^{\mathrm{b}}$, Jurga NAIMAVICIENE ${ }^{\mathrm{b}}$ \\ ${ }^{a}$ Department of Civil Engineering and Architecture, School of Engineering, \\ Tallinn University of Technology, Ehitajate tee 5, 19086 Tallinn, Estonia \\ ${ }^{b}$ Department of Construction Management and Real Estate, Faculty of Civil Engineering, \\ Vilnius Gediminas Technical University, Sauletekio al. 11, LT-10223, Vilnius, Lithuania
}

Received 01 June 2017; accepted 04 June 2017

\begin{abstract}
Refurbishment of the building façades of residential buildings, including insulation, is often considered as the most energy efficient renovation measure with the largest potential. One of the solutions to increase energy efficiency is the selection of the appropriate insulation materials of the external walls. The article proposes the approach for selection of the insulation material based on SAW multiple criteria assessment method. The proposed methodology is applied for the case of insulation material selection in refurbishment of 12-storey building in Vilnius, Lithuania. Research reveals that rock wool outperforms other materials by thermal conductivity, light weigh, water vapour diffusion resistance, highest flammability class, durability and lowest emission of $\mathrm{CO} 2$ and is an efficient insulation to be used for sustainable refurbishment solutions.
\end{abstract}

Keywords: refurbishment, façade, insulation materials, multiple criteria assessment, SAW.

\section{Introduction}

In the European Union (EU), the building sector uses $40 \%$ of total final energy consumed (of which heating and cooling accounts around $70 \%)$ and releases about $36 \%$ of total $\mathrm{CO}_{2}$ emissions (EU 2010). Consequently, the European energy policy has an explicit orientation towards the conservation and rational use of energy in buildings such as the Energy Performance of Buildings Directive (EPBD) (2010/31/EU (EC 2010)) states. The EU aims to reduce GHG emissions by $20 \%$ below the levels of 1990 for 2020, 40\% for 2030, and an additionally from 80 to $95 \%$ in 2050 (EC 2011).

Most of the European countries have succeeded in reducing energy consumption of new dwellings by more than $50 \%$ without increasing their building cost, and therefore energy efficiency has achieved great acceptance among building owners (Kaklauskas et al. 2006). However, these buildings represent about $20 \%$ of the building stock but consume only $5 \%$ of the energy. Even if all future buildings were to be built so that their electrical energy and heat energy demands were very low, it would still only mean that the increase in energy demand would be reduced. It would not reduce present demand. Therefore, for future years, measures taken in existing buildings will have the most significant effect on the total energy demands in the building stock (Asadi et al. 2012). Moreover, 75\% of buildings for 2050 are already built in Europe. Also, nearly 40\% of all residential buildings in the EU were built before 1960 and almost $84 \%$ are at least 20 year-old (OECD/ IEA 2013).

In view of climate change, aging housing stocks and heavy energy consumption, it is important to promote integrated refurbishment of the residential areas, and to understand the importance of efficient mod- 
ernization, deployment of new technology and use of renewable energy resources (Raslanas et al. 2011; Sulakatko et al. 2016). According to Asadi et al. (2014), refurbishment of the existing buildings offers significant opportunities for improving occupants' comfort and well-being, reducing global energy consumption and greenhouse gas emissions. This is being considered as one of the main approaches to achieve sustainability in the built environment at relatively low cost and high uptake rates.

With every year number of building refurbishment works is growing and in many economically developed countries worldwide is now taking about $50 \%$ of all building construction market (Cattano et al. 2013; Thollander et al. 2012; Teo, Runeson 2012). The main reason for this tendency is the increasing price of energy and the will of stakeholders to pay lower bills. According to the changes in construction market it can be predicted that today's homes will comprise at least $80 \%$ of the 2050 housing stock and because of rising prices on energy they will need to be retrofitted for better energy performance (Foley 2012).

The growth in building refurbishment works is creating a demand for suitable materials, retrofitting techniques and research (Zagorskas et al. 2014). Although a wide range of retrofit technologies is already available, methods to identify the most suitable set of retrofit actions for particular projects are still a major technical and methodological challenge (Asadi et al. 2014).

The façade is a primary system and a particular focus in high performance buildings. It is a fundamental system in deep energy retrofits, which are comprehensive interventions aimed at energy reductions greater than 50\% (The American Institute...2013). The façade has evolved over time, accommodating a broader range of functionality and performance. The result of this evolution of façade technology is the availability of higher performing products and materials that present retrofit opportunities for existing façade systems. These retrofit opportunities are not the only drivers of façade renovation. Weathering processes, materials deterioration, and conditions of use decrease façade performance over time (Martinez et al. 2015). Even before reaching the end of their service live, depending upon system type and application, a façade system may require maintenance and partial renovation around 20 or 30 years of being built (Giebeler 2009).
Building energy refurbishment in general and façade retrofit in particular, are relatively new areas of practice and research as the post-war buildings are aging and energy prices and concerns are increasing. Retrofitting of external walls and building façades of residential buildings, including insulation, is often considered as the most energy efficient renovation measure with the largest potential (Paiho et al. 2015).

Most national building regulations that mandate thermal insulation of building envelopes were introduced after the1970s, following the energy crisis (Balaras et al. 2005). In addition, compared to current regulations the first thermal insulation requirements were quite moderate. So, the energy saving potential is the largest in the oldest non-retrofitted buildings (Paiho et al. 2015).

Lithuania has the same energy efficiency goals as the rest of the European Union. Major energy efficiency and $\mathrm{CO}_{2}$ emission savings have to be achieved by 2050 . The housing sector is the second largest energy consumer in Lithuania, and one with a high saving potential. Lithuania, as most European countries, experienced a post-war construction boom. More than $70 \%$ of the residential buildings in Lithuania were built between 1960 and 1993. The majority of the buildings are, therefore, in bad condition and currently require refurbishment. As it was previously discussed, refurbishment of façades has highest potential and its thermal insulation is the component of major importance.

Thermal insulation of buildings is a significant factor in maintaining the thermal comfort of the building's users, particularly if we take extreme temperatures in winter and summer into consideration. The insulation reduces undesirable losses of warmth (in winter) or excessive heat (in summer) and decreases energy demand for heating and cooling. Thermal insulation in walls and roofs reduces overall need for air conditioning as well as the power required for air conditioning when it is used, further decreasing annual energy costs. Proper insulation of buildings also brings additional benefits by reducing pollution emissions, including $\mathrm{CO}_{2}$ (Dylewski, Adamczyk 2014).

Building thermal insulation materials are products that have various properties including mechanical strength, fire resistance, acoustic performance, hydrothermal property, etc. (Kono et al. 2015). In the case of the construction of insulation façade systems, the environmental implications are different depending on the type of façade system, the insulation materials used 
and the location of the building (Sierra-Pérez et al. 2016). Among the building materials, the thermal insulation materials have recently drawn increased interest in the environmental field (i.e. Jelle 2011; Pargana et al. 2014). In addition, Life Cycle Impact Assessment (LCIA) of the materials is gaining its importance with the growing interest on the design of sustainable buildings. However, as noted by Kono et al. (2015) there is limited number of studies, that deal with the selection of the material considering multiple aspects.

The main aim of this article is to propose the multiple criteria based approach for selection of insulation materials for refurbishment of multi-storey buildings in Lithuania.

\section{Literature review}

In order to design and implement an efficient building refurbishment, it is necessary to carry out an exhaustive investigation of all solutions that form it. The efficiency level of the considered building's refurbishment depends on a great many of factors, including: cost of refurbishment, annual fuel economy after refurbishment, tentative pay-back time, harmfulness to health of the materials used, aesthetics, maintenance properties, functionality, comfort, sound insulation and durability, etc. (Kaklauskas et al. 2005).

In light of the current EU guidelines in the energy field, improving building envelope performance cannot be separated from the context of satisfying the environmental sustainability requirements, reducing the costs associated with the life cycle of the building as well as economic and financial feasibility. Therefore, identifying the "optimal" energy retrofit solutions requires the simultaneous assessment of several factors and thus becomes a problem of choice between several possible alternatives (Donnarumma, Fiore 2017).

There are a number of models and methods developed to assess conditions and support decisions pertaining to building refurbishment. These methodologies can be categorized into two main approaches: the models in which alternative retrofit solutions are explicitly known a priori and the models in which alternative retrofit solutions are implicitly defined in the setting of an optimization model (Asadi et al. 2014). However, comparing the different methods to assess the effectiveness of energy efficiency solutions, only two objective functions are usually used, such as: primary energy consumption and life-cycle cost, accord- ing to the EPBD recast-2010 methodology; energy consumption and thermal comfort; single-score metric of environmental impact (e.g. Eco Point) and life cycle cost; carbon dioxide equivalent emissions and life cycle cost; energy consumption and investment cost; carbon dioxide equivalent emissions and investment cost; or operating cost and thermal comfort. In a reduced number of studies, a greater number of objective functions are proposed (three or more), such as: energy consumption, operating cost, investment cost and payback period (PBP); energy consumption, thermal comfort and life-cycle cost; energy consumption, thermal comfort and investment cost or energy consumption, carbon dioxide equivalent emissions and investment cost (Lizana et al. 2016).

The most common a priori approach is one in which the decision maker assigns weights to each criterion, the weighted sum of the criteria then forming a single design criterion. It is then possible to find the single design solution that optimizes the weighted sum of the criteria (Asadi et al. 2014). In other words, alternative refurbishment solutions of the buildings are evaluated by Multiple Criteria Decision Assessment (MCDA) methods.

Gero et al. (1983) were among the first to propose a multi-criteria analysis model to be used at the process of building design in order to explore the trade-offs between the building thermal performance and other criteria such as capital cost and usable area. More recently, other researchers have also employed MCDA techniques to similar problems. Kaklauskas et al. (2005) developed a multivariate design method for building's refurbishment. This method was practically applied for refurbishment solutions of Vilnius Gediminas Technical University building. Moreover, Kaklauskas et al. (2006) used COPRAS method for the selection of low-e windows in retrofit of public buildings. Ginevičius et al. (2008) applied six multiple criteria methods (SAW, TOPSIS, VIKOR, GV, VS, COPRAS) for selection of building insulation solutions. Donath and Lobos (2009) created a new decision support system tool based on the building information modelling (BIM) software platform. This tool generates several options for building envelopes according to the required parameters. A new decision support system for the integrated assessment of thermal insulation solutions with emphasis on recycling potential was presented by Anastaselos et al. (2011). 
Asadi et al. (2012) defined a multi-objective optimization model for building retrofits in terms of energy consumption and investment cost. Fesanghary et al. (2012) developed a multi-objective optimization model to find an optimal building envelope design (wall, roof, ceiling and floor construction materials as well as glazing type) that minimizes the life cycle costs (LCC) and carbon dioxide equivalent emissions.

Zavadskas et al. (2012) used a joint method of the latters' criteria of optimality called WASPAS (Weighted Aggregated Sum Product ASsessment) for ranking of façades. Four facade's alternatives in terms of twelve criteria, involving physical, structural, economic, environmental and performance properties, were evaluated. Three criteria of optimality were applied and alternative decisions were ranked by Šaparauskas et al. (2010, 2011). Moreover, Zavadskas et al. (2013) evaluated four building facades' alternatives for public or commercial buildings considering a set of twelve criteria. Ranking of alternatives was performed applying WSM, WPM methods, a joint criterion of weighted aggregation of the latter methods, also the ratio system and the reference point approach as a parts of MOORA and the full multiplicative form.

Penna et al. (2015) investigated the relationship between the initial characteristics of residential buildings and the definition of optimal retrofit solutions in terms of either maximum economic performance, or energy consumption minimization towards nZEBs behaviour for the lowest achievable thermal discomfort.

Šiožinyte et al. (2014) applied TOPSIS Grey (Technique for Order Preference by Similarity to Ideal Solution with grey numbers) and AHP (Analytic Hierarchy Process) methods for the case study of upgrading the old vernacular building.

Almeida and De Freitas (2016) proposed a methodology to optimize the insulation thickness of the external walls and roof on school buildings retrofit. The procedure includes the optimization of the building performance considering the following objectives: the minimization of the annual heating load; the minimization of the discomfort in the classrooms due to overheating; and the minimization of the life cycle cost of retrofitting external walls and roof. This methodology was applied for two Portuguese school buildings.

Rasiulis et al. (2016) proposed the decision model for selection of optimal combinations of modernization measures. The presented algorithm of decision synthesis method comprises method for integrated significance determination of efficiency indicators and multiple criteria decision methods SAW, COPRAS and TOPSIS.

Some of the authors used MCDA methods for selection of the best thermal insulation alternative (i.e. Civic, Vucijak 2014; Zagorskas et al. 2014; Ruzgys et al. 2014, Kono et al. 2015). Civic and Vucijak (2014) considered several options for buildings' insulation in Sarajevo and evaluated them by selected criteria, after that multi-criteria optimization method VIKOR was applied to rank the options and select the best one. Zagorskas et al. (2014) have analysed thermal insulation alternatives of historic brick buildings in Baltic Sea Region. The five modern insulation materials were selected; measurements made and best alternative found by using TOPSIS method with grey numbers. Ruzgys et al. (2014) studied six cases of residential building modernization in Lithuania estimating criteria that are among the most important for implementation of apartment building modernization, such as the total cost of the external wall modernization, simple payback period, work duration, and other parameters related to the characteristics of thermal insulation systems. SWARA-TODIM multi-criteria decision-making method was used to rank the alternatives. Kono et al. (2015) applied MCDA on common insulation materials (stone wool and expanded polystyrene (EPS)) to examine its effectiveness when selecting more environmentally friendly material. The study applied analytical hierarchy process (AHP) method.

From the review of literature it can be overserved that MCDA methods gain popularity in refurbishment solutions. However, studies on thermal insulation materials selection are still limited. Some of the mathematical models proposed by the authors are rather complicated, thus rarely applied in practice. To overcome this limitation authors propose to apply the simplified methodology for selection of the insulation materials.

\section{Methodology}

The decision maker in the retrofitting of existing buildings faces the challenge of solving a multi-objective optimization problem, taking into account multiple, and usually competitive, objectives and variables. Thus, the selection of the correct method and variables to identify the most effective refurbishment solutions is still a technical challenge (Ma et al. 2012). Authors of this 
paper aimed to provide simple and clearly understandable assessment approach, thus MCDA method SAW (Simple Additive Weighting) was selected.

Simple Additive Weighting (SAW) method was summarized by MacCrimmon (1968). It is the oldest, most widely known and practically used method. The results clearly demonstrate the main concept of multiple criteria evaluation methods - the integration of the criteria values and weights into a single magnitude. This is also reflected in its title (Podvezko 2011).

Selection of the thermal insulation for refurbishment of façades is illustrated in Figure 1. Multiple criteria assessment of thermal insulation alternatives is performed by SAW method as follows.

Stage 1. Development of the decision-making matrix:

$$
P=\left[x_{i j}\right]_{[m \times n]} ; i=\overline{1, m} ; j=\overline{1, n},
$$

where: $n$ - number of alternatives; $m$ - number of attributes; $x_{i j}$ - the attribute value of the $j^{\text {th }}$ alternative.

Here also the best values of each parameter are determined according to the Eq. (2):

$$
x_{i}^{*}=\min _{i} x_{i j},
$$

if preferable is minimum of $i^{\text {th }}$ attribute;

if preferable is maximum of $i^{\text {th }}$ attribute.

$$
x_{i}^{*}=\max _{i} x_{i j},
$$
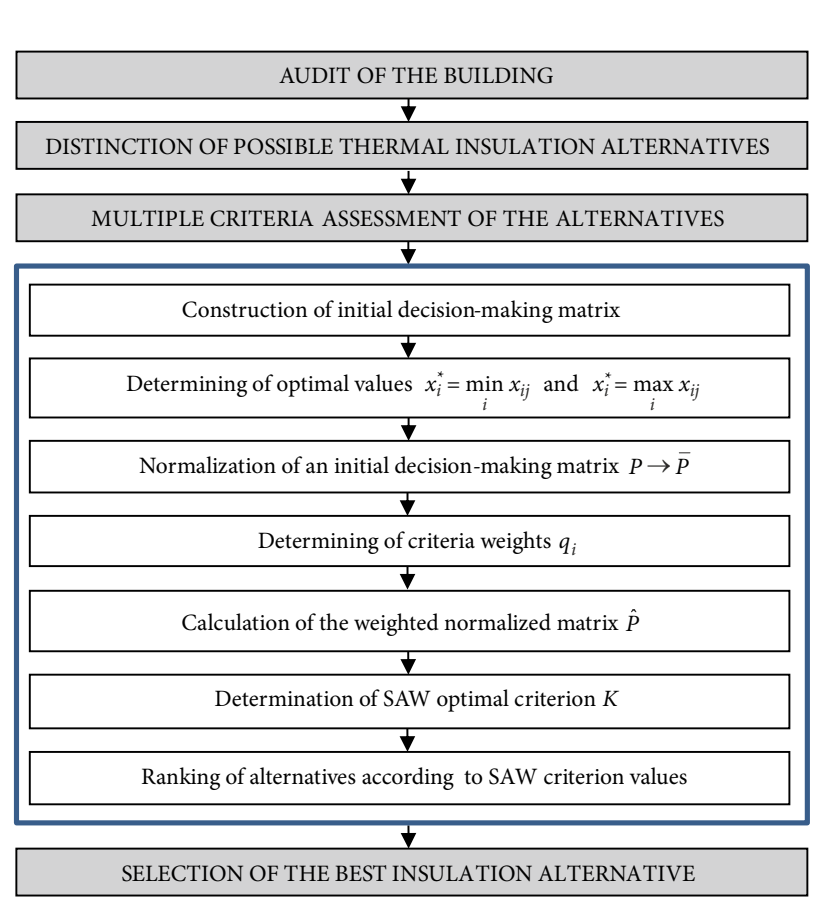

Fig. 1. Model for selection of the thermal insulation alternatives
Stage 2. Performing normalization of the decisionmaking matrix. The normalized values of normalized decision-making matrix $\bar{P}$ are calculated according to the Eq. (3):

$$
\bar{x}_{i j}=\frac{\min _{i} x_{i j}}{x_{i j}},
$$

if preferable is minimum of $i^{\text {th }}$ attribute;

$$
\bar{x}_{i j}=\frac{x_{i j}}{\max _{i} x_{i j}},
$$

if preferable is maximum of $i^{\text {th }}$ attribute.

Stage 3. Defining weighted normalized matrix. Values of the matrix are calculated by multiplying values of $\bar{P}$ matrix by corresponding weights of significances of each attribute:

$$
\hat{P}=\left[q_{i} \bar{x}_{i j}\right]_{[m \times n]} ; i=\overline{1, m} ; j=\overline{1, n},
$$

Stage 4. Defining efficiency criterion for each $j^{\text {th }}$ alternative:

$$
K_{j}=\sum_{i=1}^{m} \hat{x}_{i j} ; i=\overline{1, m} ; j=\overline{1, n} .
$$

Optimum variant and ranks of the alternatives are established by size $K$ :

$$
K=\left\{a_{j} \mid \max _{j} \sum_{i=1}^{m} q_{i} \bar{x}_{i j}\right\} ; i=\overline{1, m} ; j=\overline{1, n} ; \sum_{i=1}^{m} q_{i}=1 . \quad \text { (6) }
$$

\section{Case study: selection of insulation materials for multi-storey building in Buivydiskiu st. 15, Vilnius}

\subsection{Description of the building}

The selected building is located in the capital of Lithuania - Vilnius, Seskine district (Fig. 2). It was built in Soviet era, in 1987. The building is 12 storeys high.

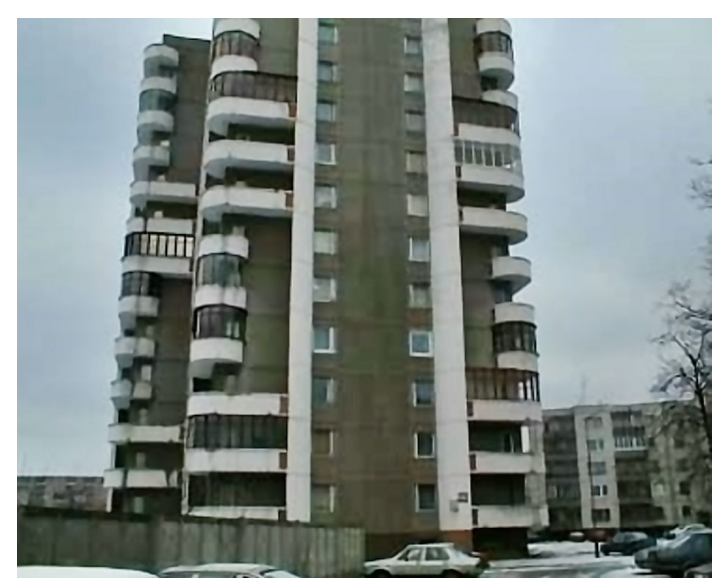

Fig. 2. Multi-storey building at Buivydiskiu st. 15, Vilnius 
Walls are constructed of prefabricated panels. Currently this building is 30 years old and is energy inefficient. Average cost of heating for year 2015-2016 is $1.13 \mathrm{EUR} / \mathrm{m}^{2}$ and exceeds costs of similar refurbished buildings by more than $60 \%$. To improve the energy efficiency of the building, immediate refurbishment is necessary.

\subsection{Thermal insulation alternatives}

The European market of insulation materials is still dominated by two groups of products. Inorganic fibrous materials account for $57 \%$ of the market, primarily consisting of glass wool (GW) (39\%) and stone wool (SW) (18\%). Organic foamy materials account for approximately $42 \%$ of the market, the most common of which is expanded polystyrene (EPS) (26\%), followed by polyurethane (PU) (10\%) and extruded polystyrene (XPS) (6\%) (Larsson et al. 2012).

Bjørn (2011) proposed an alternative classification scheme (see Table 1). Author concludes that no single thermal insulation material is suitable for all applications. According to the author, future potential materials include nano-insulation, dynamic insulation, and the load-bearing insulation material NanoCon (Bjørn 2011). Other authors proposed new insulation solutions as insulation from hemp-polylactide fibres (Stapulionienè et al. 2016), processed straw (Vejelienè 2012) as well as new building orientation solutions (Hamdani et al. 2014).

In this article practical task of renovation is being solved, thus traditional thermal building insulation materials that correspond to building properties are chosen: styrofoam, rock wool and polyurethane foam. In Lithuania these materials are in common used for refurbishment purposes.

Table 1. The division of thermal insulation materials by Bjørn (2011) (cited from Dylewski, Adamczyk 2014)

\begin{tabular}{|l|l|}
\hline \multicolumn{1}{|c|}{ Classification } & \multicolumn{1}{c|}{ Example materials } \\
\hline $\begin{array}{l}\text { Traditional } \\
\text { thermal building } \\
\text { insulation }\end{array}$ & $\begin{array}{l}\text { Mineral wool; expanded polystyrene } \\
\text { (EPS); extruded polystyrene (XPS); } \\
\text { cellulose; cork; polyurethane (PUR) }\end{array}$ \\
\hline $\begin{array}{l}\text { State-of-the-art } \\
\text { thermal building } \\
\text { insulation }\end{array}$ & $\begin{array}{l}\text { Vacuum insulation panels (VIP); gas-fi } \\
\text { lled panels (GFP); aerogels; phase change } \\
\text { materials (PCM) }\end{array}$ \\
\hline $\begin{array}{l}\text { Possible future } \\
\text { thermal building } \\
\text { insulation }\end{array}$ & $\begin{array}{l}\text { Vacuum insulation materials (VIM); } \\
\text { gas insulation materials (GIM); nano- } \\
\text { insulation materials (NIM); dynamic } \\
\text { insulation materials (DIM); concrete and } \\
\text { applications of NIMs; NanoCon }\end{array}$ \\
\hline
\end{tabular}

Styrofoam has good insulating properties, relatively low cost and easy mount. Today is one of the most popular insulation materials. Styrofoam is resistant to temperatures over $80^{\circ} \mathrm{C}$ (Civic, Vucijak 2014).

Rock wool has a high resistance to fire; it is vapour-permeable and partially waterproof. It is resistant to aging and decay, and has a high compressive strength. Rock wool is obtained from the mineral stone, dolomite, basalt and diabase with the addition of coke (Civic, Vucijak 2014).

Polyurethane is widely used because it has a lot of good insulating properties. Polyurethane has a good resistance to humidity and temperature changes. One of the drawbacks is that the polyurethane is more expensive than styrofoam and fiberglass. Polyurethane is resistant to temperatures up to $250{ }^{\circ} \mathrm{C}$ briefly, so that the panel of polyurethane foam is suitable as a substrate. Polyurethane foam can spurt on the surface or in a cavity (Civic, Vucijak 2014).

\subsection{Assessment criteria and their weights}

In Lithuania thermal insulation materials are usually selected by assessment of two criteria: price and thermal properties. However, as it was previously discussed, selection of material is multi-objective problem, thus extensive list of quantitative and qualitative criteria should be set.

According to Dylewski and Adamczyk (2014), when selecting an insulating material, it is important to take the following criteria into consideration: 1) thermal conductivity; 2) diffusion (penetration) of water vapour; 3) class of flammability; 4) resistance to chemical factors; 5) resistance to biological factors; 6) mechanical endurance (ability to transfer loads); 7) impact on the environment.

Kono et al. (2015) emphasised mechanical strength, fire resistance, acoustic performance, hygrothermal property of the materials. According to authors, Life Cycle Impact Assessment (LCIA) is also very important.

Civic and Vucijak (2014) in Sarajevo assessed materials by criteria as follows: costs of insulation, density, specific heat, thermal conductivity, water vapour diffusion resistance factor. Zagorskas et al. (2014) used similar criteria: cost of the material; complexity of the installation; heat transfer coefficient; loss of space after installing the selected material; hydrophobic/ moisture properties of the material. 
Basing on the literature review, the list of criteria was developed by authors specially for the case (see Table 2). Criteria represent economy of decisions, performance parameters, environmental impact of particular materials, structural and physical properties.

Second very important step is assessment of the weights of criteria. For this purpose, three project managers, working in construction sector (refurbishment projects) and two associate professors from Vilnius Gediminas Technical University, with $\mathrm{PhDs}$ in technological sciences (civil engineering) were surveyed. The experts were briefed and had to rank each criterion on a 10-point scale, where 10 means a very important criterion and 1 means an insignificant crite- rion. According to survey results, criteria weights were calculated by Eq. (7):

$$
q_{i}=\frac{s_{i}}{\sum_{i=1}^{r} s_{i}},
$$

where $s_{i}$ - estimated significance of the $i^{\text {th }}$ attribute, $r$ - number of experts.

Assessment results revealed that experts give priorities to commonly used criteria: costs of insulation, thermal, conductivity, water vapor diffusion resistance and durability. Small attention was given to $\mathrm{CO}_{2}$ emissions (Table 2).

Reliability of the obtained weights was assessed by calculating the Kendall's (1970) coefficient of concord-

Table 2. Description of assessment criteria and their weights

\begin{tabular}{|c|c|c|c|c|c|}
\hline & Title & $\begin{array}{c}\text { Measuring } \\
\text { unit }\end{array}$ & Max/Min & Description & Weight \\
\hline$q_{1}$ & $\begin{array}{l}\text { Costs of } \\
\text { insulation for } \\
U=0.40 \mathrm{~W} / \mathrm{m}^{2} \mathrm{~K}\end{array}$ & $\mathrm{EUR} / \mathrm{m}^{3}$ & Min & $\begin{array}{l}\text { Measured by the known open market price of the product. Direct and } \\
\text { indirect costs are evaluated. }\end{array}$ & 0.178 \\
\hline$q_{2}$ & $\begin{array}{l}\text { Compressive } \\
\text { strength }\end{array}$ & $\mathrm{kPa}$ & Max & $\begin{array}{l}\text { Choosing insulation with the right compressive strength is vital to en- } \\
\text { sure long-term performance. The compressive strength of insulation is } \\
\text { a good indicator of its ability to prevent crushing. Values are estimated } \\
\text { from materials' specifications. }\end{array}$ & 0.098 \\
\hline$q_{3}$ & $\begin{array}{l}\text { Weight of the } \\
\text { material }\end{array}$ & $\mathrm{kg} / \mathrm{m}^{3}$ & Min & $\begin{array}{l}\text { The lower the weight of material, the lower load of the house walls and } \\
\text { foundations. Values are estimated from materials' specifications. }\end{array}$ & 0.044 \\
\hline$q_{4}$ & $\begin{array}{l}\text { Coefficient } \\
\text { of thermal } \\
\text { conductivity }\end{array}$ & $\mathrm{m}^{2} \cdot \mathrm{K} / \mathrm{W}$ & Min & $\begin{array}{l}\text { Thermal conductivity - is a property of a substance to transfer the heat. } \\
\text { This feature described the thermal conductivity coefficient. The lower } \\
\text { the value, the better are the insulating properties of the material. Esti- } \\
\text { mated from materials' specifications. }\end{array}$ & 0.167 \\
\hline$q_{5}$ & $\begin{array}{l}\text { Water vapour } \\
\text { diffusion } \\
\text { resistance }\end{array}$ & $\begin{array}{l}M^{\star} h / \\
\left(S^{\star} t^{\star} P\right)\end{array}$ & Min & $\begin{array}{l}\text { Water vapour diffusion resistance factor is the resistance of material to } \\
\text { the abandonment of water vapour into air, describes how water vapour } \\
\text { penetrates through the material. If the temperature of the buildings is } \\
\text { reducing, the steam is converted into dew and it favours to formation } \\
\text { of moisture. The smaller value of this factor means greater permeability. } \\
\text { Estimated from materials' specifications. }\end{array}$ & 0.138 \\
\hline$q_{6}$ & Durability & years & Max & $\begin{array}{l}\text { Maximum durability of the material in years. Estimated according to } \\
\text { specifications. }\end{array}$ & 0.135 \\
\hline$q_{7}$ & $\begin{array}{l}\text { Flammability } \\
\text { class }\end{array}$ & points & Max & $\begin{array}{l}\text { Resistance to fire, estimated by flammability class. Estimated by points } \\
\text { according to the class (class A } 1-7 ; \mathrm{A} 2-6, \mathrm{~B}-5 ; \mathrm{C}-4 ; \mathrm{D}-3 ; \mathrm{E}-2 \text {; } \\
\mathrm{F}-1 \text { ). Estimated from materials' specifications. }\end{array}$ & 0.040 \\
\hline$q_{8}$ & $\begin{array}{l}\text { Time of } \\
\text { completion }\end{array}$ & $\begin{array}{l}100 \mathrm{~m}^{2} / \\
\text { hour }\end{array}$ & Min & $\begin{array}{l}\text { Number of working hours required to install } 100 \mathrm{~m}^{2} \text { of the insulation. } \\
\text { Assessed by SISTELA software. }\end{array}$ & 0.025 \\
\hline$q_{9}$ & $\begin{array}{l}\text { Complexity of } \\
\text { the installation }\end{array}$ & points & Min & $\begin{array}{l}\text { Some materials are more difficult to install than others; some of them } \\
\text { require specific knowledge. The complexity level is from } 1 \text { - fairly sim- } \\
\text { ple/everyone can do it; } 2 \text { - normal/requires the craftsmen with some } \\
\text { practice; } 3 \text { - average/requires craftsmen with more knowledge and } \\
\text { skills, } 4 \text { - complex/requires person understanding the risks and theory } \\
\text { of moisture regimen and thermal conductivity, } 5 \text { - highly problematic/ } \\
\text { difficult to apply without high risk of damage in the future). }\end{array}$ & 0.098 \\
\hline$q_{10}$ & $\begin{array}{l}\text { Emission of } \\
\mathrm{CO}_{2}\end{array}$ & $\mathrm{kgCO}_{2} / \mathrm{kg}$ & Min & $\begin{array}{l}\text { Carbon dioxide emissions of the material. Estimated according to find- } \\
\text { ings of Civic and Vucijak (2014) }\end{array}$ & 0.076 \\
\hline
\end{tabular}


ance, which express the agreement of the respondents' opinions. There were no reiterated ranks, thus the coefficient of concordance was calculated according to the Eq. (8):

$$
W=\frac{12 S}{r^{2}\left(m^{3}-m\right)} ; W \in[0 ; 1],
$$

where $S$ is the total square deviation of the rankings of each attribute; $r$ - the number of experts and $m$ - the number of evaluation attributes (criteria).

Obtained concordance coefficient is equal to 0.96 , meaning that opinions of experts were highly consistent and the determined weights can be used for further calculations.

\subsection{Multiple criteria assessment of the alternatives}

Following algorithm of SAW method, initial decisionmaking matrix was created (see Table 3). According to Eq. (3) normalisation of the matrix was performed (Table 4) and according to Eq. (4) the weighed matrix was calculated. Finally the efficiency of each alternative was calculated according to Eq. (5) (see Table 5).

Table 3. Decision-making matrix

\begin{tabular}{|c|c|c|c|c|}
\hline & \multirow{2}{*}{$\begin{array}{c}\text { Max/ } \\
\text { Min }\end{array}$} & \multicolumn{3}{|c|}{ Alternatives } \\
\hline & & Styrofoam & $\begin{array}{l}\text { Rock } \\
\text { wool }\end{array}$ & $\begin{array}{l}\text { Polyurethane } \\
\text { foam }\end{array}$ \\
\hline $\begin{array}{l}\text { Costs of insulation } \\
\text { for } \\
U=0.40 \mathrm{~W} / \mathrm{m} 2 \mathrm{~K}\end{array}$ & Min & 15.9 & 23.13 & 16.19 \\
\hline $\begin{array}{l}\text { Compressive } \\
\text { strengh }\end{array}$ & Max & 70 & 45 & 242 \\
\hline $\begin{array}{l}\text { Weight of the } \\
\text { material }\end{array}$ & Min & 16.4 & 90 & 45 \\
\hline $\begin{array}{l}\text { Coefficient } \\
\text { of thermal } \\
\text { conductivity }\end{array}$ & Min & 0.039 & 0.036 & 0.028 \\
\hline $\begin{array}{l}\text { Water vapour } \\
\text { diffusion } \\
\text { resistance }\end{array}$ & Min & 0.06 & 0.3 & 0.05 \\
\hline Durability & Max & 25 & 50 & 20 \\
\hline Flammability class & Max & 2 & 7 & 5 \\
\hline $\begin{array}{l}\text { Time of } \\
\text { completion }\end{array}$ & Min & 80 & 94 & 20 \\
\hline $\begin{array}{l}\text { Complexity of the } \\
\text { installation }\end{array}$ & Min & 1 & 2 & 2 \\
\hline Emission of $\mathrm{CO}_{2}$ & Min & 1.28 & 1.01 & 3.48 \\
\hline
\end{tabular}

Calculations revealed the order of insulation materials preferences: Rock wool (RW) $\succ$ Polyurethane foam (PU) $\succ$ Styrofoam (EPS).

The obtained results are consistent with findings of Kono et al. (2015). Authors revealed that when compression strength is top priority, EPS is superior to rock wool. With all the other cases, rock wool was preferable over EPS. Even without weighting of criteria it is clear that rock wool outperforms other materials by thermal conductivity, light weigh, water vapour diffusion resistance, highest flammability class, durability and lowest emission of $\mathrm{CO}_{2}$.

An estimated efficiency of other insulation materials is relatively similar. Polyurethane foam outperforms other materials by very high compressive strength and low time costs, while styrofoam - by lowest material costs and easy installation. Latter properties of styrofoam were also recognised by Civic and Vucijak (2014).

Even the price is higher, considering other properties, it is recommended to choose rock wool for the insulation of the multi-storey building in Buivydiskiu st. 15.

Table 4. Normalised decision-making matrix

\begin{tabular}{|l|c|c|c|c|}
\hline & \multirow{2}{*}{$\begin{array}{c}\text { Max/ } \\
\text { Min }\end{array}$} & \multicolumn{3}{|c|}{ Slternatives } \\
\cline { 3 - 5 } & Styrofoam & $\begin{array}{c}\text { Rock } \\
\text { wool }\end{array}$ & $\begin{array}{c}\text { Polyurethane } \\
\text { foam }\end{array}$ \\
\hline $\begin{array}{l}\text { Costs of insulation } \\
\text { for } \\
U=0.40 \mathrm{~W} / \mathrm{m} 2 \mathrm{~K}\end{array}$ & Min & 1.000 & 0.687 & 0.982 \\
\hline $\begin{array}{l}\text { Compressive } \\
\text { strengh }\end{array}$ & Max & 0.289 & 0.186 & 1.000 \\
\hline $\begin{array}{l}\text { Weight of the } \\
\text { material }\end{array}$ & Min & 1.000 & 0.182 & 0.364 \\
\hline $\begin{array}{l}\text { Coefficient } \\
\text { of thermal } \\
\text { conductivity }\end{array}$ & Min & 0.718 & 0.778 & 1.000 \\
\hline $\begin{array}{l}\text { Water vapour } \\
\text { diffusion } \\
\text { resistance }\end{array}$ & Min & 0.200 & 1.000 & 0.167 \\
\hline Durability & Max & 0.500 & 1.000 & 0.400 \\
\hline Flammability class & Max & 0.286 & 1.000 & 0.714 \\
\hline $\begin{array}{l}\text { Time of } \\
\text { completion }\end{array}$ & Min & 0.250 & 0.213 & 1.000 \\
\hline $\begin{array}{l}\text { Complexity of the } \\
\text { installation }\end{array}$ & Min & 1.000 & 0.500 & 0.500 \\
\hline Emission of CO 2 & Min & 0.789 & 1.000 & 0.290 \\
\hline
\end{tabular}


Table 5. Weighted decision-making matrix

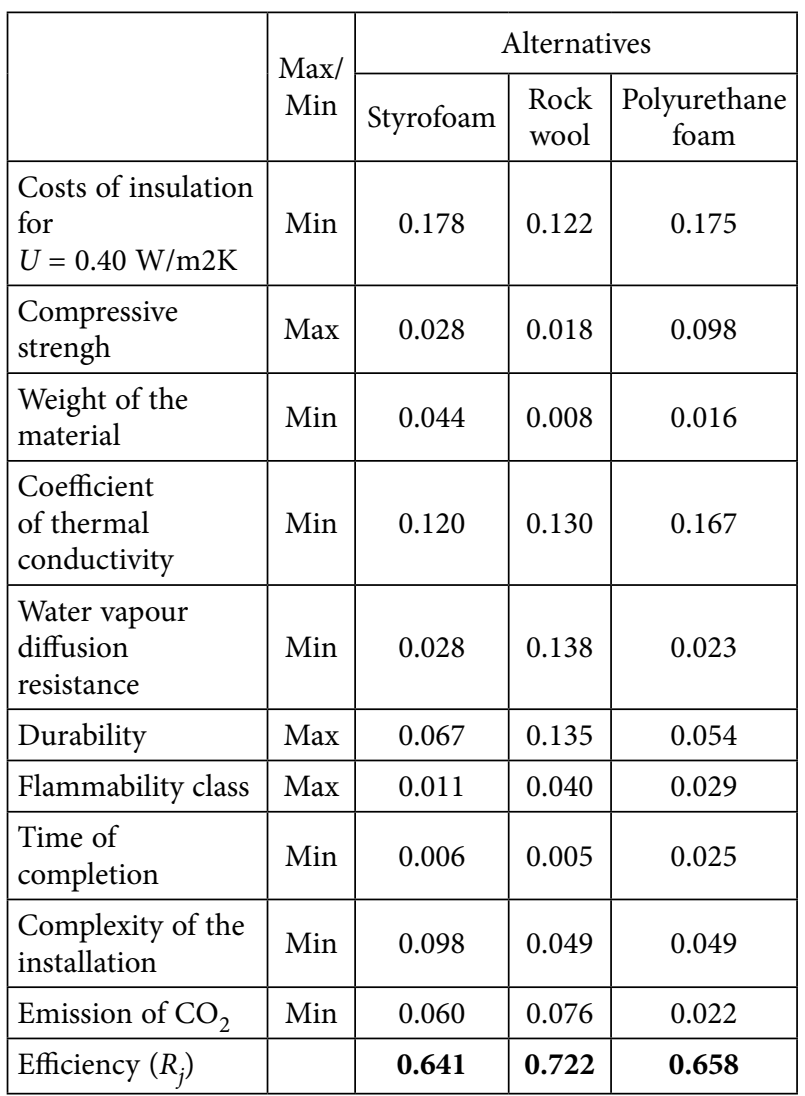

\section{Conclusions}

Most buildings standing today will be a part of the building stock in 2050. Refurbishment of the existing buildings offers significant opportunities for improving occupants' comfort and well-being, reducing global energy consumption and greenhouse gas emissions. The facade is a primary system in high performance buildings. In terms of energy, the façade is a fundamental system in deep energy retrofits, which are comprehensive interventions aimed at energy reductions greater than $50 \%$.

Building thermal insulation materials are products that have various properties including mechanical strength, durability, thermal conductivity, fire resistance, acoustic and hydrothermal performance, etc. However, in Lithuania thermal insulation materials are usually selected by assessment of two criteria: price and thermal properties. In light of the current EU guidelines, improving building façade performance cannot be separated from the context of satisfying the environmental sustainability requirements. Therefore, identifying the most efficient thermal insulation alternatives requires the simultaneous assessment of several criteria and thus becomes multiple criteria decision problem.

Authors of this paper proposed simple and clearly understandable assessment approach for selection of insulation materials based on MCDA method SAW. This approach was applied for the case of multi-storey building refurbishment in Buivydiskiu st. 15, Vilnius, Lithuania.

Three thermal insulation alternatives (EPS, RW and PU) were selected and assessed by ten criteria, representing economy of decisions, performance parameters, environmental impact, structural and physical properties. Calculations revealed the order of insulation materials preferences: Rock wool (RW) $\succ$ Polyurethane foam $(\mathrm{PU}) \succ$ Styrofoam (EPS). Rock wool outperforms other materials by thermal conductivity, light weigh, water vapour diffusion resistance, highest flammability class, durability and lowest emission of $\mathrm{CO}_{2}$. Even the price is higher, considering other properties, it is recommended to choose rock wool for the insulation of the multi-storey building in Buivydiskiu st. 15.

SAW method demonstrated the ease of its application, thus it can be successfully used in practice, when it is necessary to determine the ranking order of refurbishment alternatives according to many conflicting quantitative and qualitative criteria.

However, the study has some limitations to be mentioned. In order to achieve more accurate results, it is recommended to use more than one multiple criteria assessment method. Also, more criteria can be included into system of criteria. These limitations will be solved in future research.

\section{Acknowledgements}

This work was supported by institutional research funding of the Estonian Ministry of Education and Research IUT1-15 "Nearly-zero energy solutions and their implementation on deep renovation of buildings".

\section{Disclosure statement}

Authors do not have any competing financial, professional, or personal interests from other parties. 


\section{References}

Almeida, R. M. S. F.; De Freitas, V. P. 2016. An insulation thickness optimization methodology for school buildings rehabilitation combining artificial neural networks and life cycle cost, Journal of Civil Engineering and Management 22(7): 915-923. https://doi.org/10.3846/13923730.2014.928364

Anastaselos, D.; Oxizidis, S.; Papadopoulos, A. M. 2011. Energy, environmental and economic optimization of thermal insulation solutions by means of an integrated decision support system, Energy and Buildings 43(2-3): 686-694. https://doi.org/10.1016/j.enbuild.2010.11.013

Asadi, E.; da Silva, M. G.; Antunes, C. H.; Dias, L. 2012. A multiobjective optimization model for building retrofit strategies using TRNSYS simulations, GenOpt and MATLAB, Building and Environment 56: 370-378.

https://doi.org/10.1016/j.buildenv.2012.04.005

Asadi, E.; da Silva, M. G.; Antunes, C. H.; Dias, L.; Glicksman, L. 2014. Multi-objective optimization for building retrofit: A model using genetic algorithm and artificial neural network and an application, Energy and Buildings 81: 444-456. https://doi.org/10.1016/j.enbuild.2014.06.009

Balaras, C. A.; Droutsa, K.; Dascalaki, E.; Kontoyiannidis, S. 2005. Deterioration of European apartment buildings, Energy and Buildings 37: 515-527.

https://doi.org/10.1016/j.enbuild.2004.09.010

Bjørn, P. J. 2011. Traditional, state-of-the-art and future thermal building insulation materials and solutions - properties, requirements and possibilities, Energy and Buildings 43: 2549-2563. https://doi.org/10.1016/j.enbuild.2011.05.015

Cattano, C.; Plumblee, J. M.; Valdes-Vasquez, R.; Klotz, L. 2013. Potential solutions to common barriers experienced during the delivery of building renovations for improved energy performance: a literature review and case study, Journal of Architectural Engineering 19(special issue): 164-167. https://doi.org/10.1061/(ASCE)AE.1943-5568.0000126

Civic, A.; Vucijak, B. 2014. Multi-Criteria optimization of insulation options for warmth of buildings to increase energy efficiency, Procedia Engineering 69: 911-920. https://doi.org/10.1016/j.proeng.2014.03.070

Donath, D.; Lobos, D. 2009. Plausibility in early stages of architectural design: A new tool for high-rise residential buildings, Tsinghua Science \& Technology 14(3): 327-332. https://doi.org/10.1016/S1007-0214(09)70048-3

Donnarumma, G.; Fiore, P. 2017. A multi-criteria model for the comparison of building envelope energy retrofits, AIP Conference Proceedings 1814, 020024. https://doi.org/10.1063/1.4976243

Dylewski, R.; Adamczyk, J. 2014. Life cycle assessment (LCA) of building thermal insulation materials, Chapter 12, in Ecoefficient construction and building materials. Woodhead Publishing Limited, 267-286.

European Commission (EC). 2010. 2010/31/EU Directive of the European Parliament and of the Council of 19 May 2010 on the energy performance of buildings (recast), Official Journal of the European Communities.

European Commission (EC). 2011. Energy roadmap 2050 [online], [cited 10 April 2017]. Available from Internet: https:// ec.europa.eu/energy/sites/ener/files/documents/2012_energy_roadmap_2050_en_0.pdf
Fesanghary, M.; Asadi, S.; Geem, Z. W. 2012. Design of lowemission and energy-efficient residential buildings using a multi-objective optimization algorithm, Building and Environment 49: 245-250.

https://doi.org/10.1016/j.buildenv.2011.09.030.

Foley, H. C. 2012. Challenges and opportunities in engineered retrofits of buildings for improved energy efficiency and habitability, AIChE Journal 58(3): 658-667. https://doi.org/10.1002/aic.13748

Gero, J. S.; Dcruz, N.; Radford, A. D. 1983. Energy in context-a multicriteria model for building design, Building and Environment 18(3): 99-107. https://doi.org/10.1016/0360-1323(83)90001-X

Giebeler, G. 2009. Historical periods, in Refurbishment manual. Part C. Boston, Mass.: Birkhäuser Verlag AG.

Ginevičius, R.; Podvezko, V.; Raslanas, S. 2008. Evaluating the alternative solutions of wall insulation by multicriteria methods, Journal of Civil Engineering and Management 14(4): 2017-226. https://doi.org/10.3846/1392-3730.2008.14.20

Hamdani, M.; El Amine Bekkouche, S. M.; Benouaz, T.; Belarbi, R.; Cherier, K. M. 2014. Minimization of indoor temperatures and total solar insolation by optimizing the building orientation in hot climate, Engineering Structures and Technologies 6(3): 131-149. http://dx.doi.org/10.3846/2029882X.2014.988756

Jelle, B. P. 2011. Traditional, state-of-the-art and future thermal building insulation materials and solutions e properties, requirements and possibilities, Energy and Buildings 43(10): 2549-2563. https://doi.org/10.1016/j.enbuild.2011.05.015

Kaklauskas, A.; Zavadskas, E. K.; Raslanas, S. 2005. Multivariant design and multiple criteria analysis of building refurbishments, Energy and Buildings 37: 361-372. https://doi.org/10.1016/j.enbuild.2004.07.005

Kaklauskas, A.; Zavadskas, E. K.; Raslanas, S.; Ginevicius, R.; Komka, A.; Malinauskas, P. 2006. Selection of low-e windows in retrofit of public buildings by applying multiple criteria method COPRAS: a Lithuanian case, Energy and Buildings 38: 454-462. https://doi.org/10.1016/j.enbuild.2005.08.005

Kendall, M. G. 1970. Rank correlation methods. $4^{\text {th }}$ ed. London: Griffin.

Kono, J.; Goto, Y.; Ostermeyer, Y.; Wallbaum, H. 2015. Utilization of multi-criteria assessment on building thermal insulation materials, in The $5^{\text {th }}$ International Conference on "Green and Sustainable Innovation (ICGSI 2015) - Towards Green Growth and Green Competitiveness", 2015.

Larsson, E.; Seppänen, R.; Lecourt, M. 2012. Different types of insulation materials - introduction [online]. WoTIM Market survey [cited 10 April 2017]. Available from Internet: http://wotim.eu/Global/WoTIM/WOTIM\%20Market\%20 survey.pdf

Lizana, J.; Barrios-Padura, A.; Molina-Huelva, M.; Chacartegui, R. 2016. Multi-criteria assessment for the effective decision management in residential energy retrofitting, Energy and Buildings 129: 284-307. https://doi.org/10.1016/j.enbuild.2016.07.043

Ma, Z.; Cooper, P.; Daly, D.; Ledo, L. 2012. Existing building retrofits: methodology and state-of-the-art, Energy and Buildings 55: 889-902.

https://doi.org/10.1016/j.enbuild.2012.08.018. 
MacCrimmon, K. R. 1968. Decision making among multiple attribute alternatives: A survey and consolidated approach, RAND Memorandum, RM-4823-ARPA.

Martinez, A.; Patterson, M.; Carlson, A.; Noble, D. 2015. Fundamentals in façade retrofit practice, Procedia Engineering 118: 934-941. https://doi.org/10.1016/j.proeng.2015.08.534

OECD/IEA. 2013. Transition to sustainable buildings: Strategies and opportunities to 2050.

https://doi.org/10.1787/9789264202955-en

Paiho, S.; Seppä, I. P.; Jimenez, C. 2015. An energetic analysis of a multifunctional façade system for energy efficient retrofitting of residential buildings in cold climates of Finland and Russia, Sustainable Cities and Society 15: 75-85. https://doi.org/10.1016/j.scs.2014.12.005

Pargana, N.; Pinheiro, M. D.; Silvestre, J. D.; de Brito, J. 2014. Comparative environmental life cycle assessment of thermal insulation materials of buildings, Energy and Buildings 82: 466-481. https://doi.org/10.1016/j.enbuild.2014.05.057

Penna, P.; Prada, A.; Cappelletti, F.; Gasparella, A. 2015. Multiobjectives optimization of energy efficiency measures in existing buildings, Energy and Buildings 95: 57-69. https://doi.org/10.1016/j.enbuild.2014.11.003

Podvezko, V. 2011. The comparative analysis of MCDA methods SAW and COPRAS, Inzinerine Ekonomika-Engineering Economics 22(2): 134-146. https://doi.org/10.5755/j01.ee.22.2.310

Rasiulis, R.; Ustinovichius, L.; Vilutienè, T.; Popov, V. 2016. Decision model for selection of modernization measures: public building case, Journal of Civil Engineering and Management 22(1): 124-133. https://doi.org/10.3846/13923730.2015.1117018

Raslanas, S.; Alchimovienè, J.; Banaitienè, N. 2011. Residential areas with apartment houses: Analysis of the condition of buildings, planning issues, retrofit strategies and scenarios, International Journal of Strategic Property Management 15(2): 158-172. https://doi.org/10.3846/1648715X.2011.586531

Ruzgys, A.; Volvačiovas, R.; Ignatavičius, Č.; Turskis, Z. 2014. Integrated evaluation of external wall insulation in residential buildings using SWARA-TODIM MCDM method, Journal of Civil Engineering and Management 20(1): 103-110. https://doi.org/10.3846/13923730.2013.843585

Sulakatko, V.; Lill, I.; Witt, E. 2016. Methodological framework to assess the significance of External Thermal Insulation Composite System (ETICS) on-site activities, in Energy Procedia: SBE16 Tallinn and Helsinki Conference; Build Green and Renovate Deep, 5-7 October 2016, Tallinn and Helsinki. Elsevier, 446-454. https://doi.org/10.1016/j.egypro.2016.09.176

Šaparauskas, J.; Zavadskas, E. K.; Turskis, Z. 2010. Evaluation of alternative building designes according to the three criteria of optimality, in $10^{\text {th }}$ International Conference "Modern Building Materials, Structures and Techniques": selected papers, 1: 519-523.
Šaparauskas, J.; Zavadskas, E. K.; Turskis, Z. 2011. Selection of façade's alternatives of commercial and public buildings based on multiple criteria, International Journal of Strategic Property Management 15(2): 189-203.

https://doi.org/10.3846/1648715X.2011.586532

Sierra-Pérez, J.; Boschmonart-Rives, J.; Gabarrell, X. 2016. Environmental assessment of façade-building systems and thermal insulation materials for different climatic conditions, Journal of Cleaner Production 113: 102-113. https://doi.org/10.1016/j.jclepro.2015.11.090

Šiožinytė, E., Antuchevičienė, J.; Kutut, V. 2014. Upgrading the old vernacular building to contemporary norms: multiple criteria approach, Journal of Civil Engineering and Management 20(2): 291-298. https://doi.org/10.3846/13923730.2014.904814

Stapulionienè, R.; Tupčiauskas, R.; Vaitkus, S.; Vejelis, S. 2016. Development and investigation of thermal insulation from hemp-polylactide fibres, Engineering Structures and Technologies 8(1): 23-30. https://doi.org/10.3846/2029882X.2016.1158127

Teo, A.-L.; Runeson, G. 2012. Aspects of market differentiation in the building industry, Australasian Journal of Construction Economics and Building 1(2):14-23. https://doi.org/10.5130/ajceb.v1i2.2872

The American Institute of Architects and Rocky Mountain Institute. 2013. Deep energy retrofits: An emerging opportunity [online], [cited 10 April 2017]. Available from Internet: http://www.aia.org/aiaucmp/groups/aia/documents/pdf/ aiab099241.pdf

Thollander, P.; Rohdin, P.; Moshfegh, B. 2012. On the formation of energy policies towards 2020: challenges in the Swedish industrial and building sectors, Energy Policy 42: 461-467. https://doi.org/10.1016/j.enpol.2011.12.012

Vejelienè, J. 2012. Processed straw as effective thermal insulation for building envelope constructions, Engineering Structures and Technologies 4(3): 93-103.

https://doi.org/10.3846/2029882X.2012.730286

Zagorskas, J.; Zavadskas, E. K.; Turskis, Z.; Burinskienè, M.; Blumberga, A.; Blumberga, D. 2014. Thermal insulation alternatives of historic brick buildings in Baltic Sea Region, Energy and Buildings 78: 35-42. https://doi.org/10.1016/j.enbuild.2014.04.010

Zavadskas, E. K.; Turskis, Z.; Antucheviciene, J.; Zakarevicius, A. 2012. Optimization of weighted aggregated sum product assessment, Electronics and Electrical Engineering 6: 3-6. https://doi.org/10.5755/j01.eee.122.6.1810

Zavadskas, E. K.; Antucheviciene, J.; Šaparauskas, J.; Turskis, Z. 2013. Multi-criteria assessment of façades' alternatives: Peculiarities of ranking methodology, Procedia Engineering 57: 107-112. https://doi.org/10.1016/j.proeng.2013.04.016 
Irene LILL. Professor, Head of the Building Lifecycle Research Group within the Department of Building and Architecture at Tallinn University of Technology where she has lectures in Building technology and Construction management. Major topics for consultancy and research: Construction management and economics, simulation modelling, management strategies in construction, disaster resilience.

Loreta KANAPECKIENE. PhD, Associated Professor at Vilnius Gediminas Technical University, Faculty of Civil Engineering, Department of Construction Management and Real Estate. Defended her PhD in 2010, in the field of Civil Engineering, Technological Sciences. Author and co-author of more than 20 scientific publications and a textbook. Research interests: sustainable development, knowledge management in construction, multiple criteria decision support.

Laura TUPENAITE. PhD, Associated Professor at Vilnius Gediminas Technical University, Faculty of Civil Engineering, Department of Construction Management and Real Estate. Defended her PhD in 2010, in the field of Civil Engineering, Technological Sciences. Managing Editor of the Journal of Civil Engineering and Management, which is referred in Thomson Reuters Web of Science database. Author and co-author of more than 30 scientific publications, a monograph and 3 educational books. Research interests: renovation of the built environment, real estate finance and investments, multiple criteria decision support.

Jurga NAIMAVICIENE. PhD, Associated Professor at Vilnius Gediminas Technical University, Faculty of Civil Engineering, Department of Construction Management and Real Estate. Defended her PhD in 2008, in the field of Civil Engineering, Technological Sciences. Author and co-author of more than 20 scientific publications, a monograph and a textbook. Research interests: intelligent technologies, multiple criteria decision support in construction. 